\title{
Artificial neural networks in the prediction of fraud in integral milk powder by adding whey powder
}

\section{Raissa Oliveira Rocha Alves ${ }^{1^{*}}$ (D) Otávio Chedid Tomé1 (iD) Pollyanna Cardoso Pereira ${ }^{1}$ (D) Camila Nair Batista Couto Villanoeva ${ }^{1}$ (D) Vanelle Maria da Silva ${ }^{1}$ (D)}

\author{
IInstituto de Ciências Exatas e Tecnológicas, Universidade Federal de Viçosa (UFV), 35690-000, Florestal, MG, Brasil. E-mail: raissaalvesr@gmail.com.
} ${ }^{*}$ Corresponding author.

\begin{abstract}
This research was performed to ascertain the most suitable Artificial Neural Network ( $A N N)$ model to quantify the degree of fraud in powdered milk through the addition of powdered whey via regular standard physicochemical analyses. In this study, an evaluation was done on 103 samples with different quantities of added whey powder to whole milk powder. Using Fourier Transform Infrared Spectroscopy the fat, cryoscopy, total solids, defatted dry extract, lactose, protein and casein were analyzed. The hyperbolic tangent transformation function was used with 45 topologies, and the Holdback and $K$-fold validation methods were tested. In the Holdback method, 75\% of the database was employed for training, while $25 \%$ was used for validation. In the K-fold method, the database was categorized into five equal sized subsets, which alternated between training and validation. Of the two methods, the K-fold method was proven to have superior efficiency. Next, analysis was done on three models of multilayer perceptron networks with feedforward architecture. In Model 1, the input layer contained all the physicochemical analyses conducted, in model 2 the casein analysis was excluded, and in model 3 the routine analyses performed for dairy products was done (fat, defatted dry extract, cryoscopy and total solids). From Model 3 an ANN was derived which could satisfactorily predict fraud calculated from using the routine and standard analyses for dairy products, containing 64 nodes in the hidden layer, with $R^{2}$ of 0.9935 and RMSE of 0.5779 for training, and $R^{2}$ of 0.9964 and RMSE of 0.4358 for validation.
\end{abstract}

Key words: routine analysis, fraud detection, quality control.

Redes neurais artificiais na predição de fraude em leite em pó integral pela adição de soro lácteo em pó

RESUMO: O objetivo do trabalho foi determinar o melhor modelo de rede neural artificial (RNA) para quantificar fraude em leite em pó, pela adição de soro em pó, por meio de analises físico-químicas de rotina. Foram avaliados 103 níveis de adição de soro lácteo em pó em leite em pó integral. As análises de gordura, crioscopia, sólidos totais, extrato seco desengordurado, lactose, proteína e caseína foram realizadas por espectroscopia no infravermelho com transformada de Fourier. A função de transformação utilizada foi a tangente hiperbólica, em que testou-se 45 topologias e dois métodos de validação: holdback e k-fold. Para o método holdback, 75\% do banco de dados foi utilizado para o treinamento e 25\% para a validação. Para o método k-fold, o banco de dados foi dividido em cinco subconjuntos de mesmo tamanho que se alternavam entre treinamento e validação. $O$ método $k$-fold se mostrou mais eficiente. Três modelos de redes perceptron de múltiplas camadas com arquitetura feedforward foram analisados. No modelo 1 a camada de entrada constituía todas as análises físico-químicas realizadas, no modelo 2 excluiu-se a análise de caseína e no modelo 3 utilizou-se as análises de rotina em laticínios (gordura, extrato seco desengordurado, crioscopia e sólidos totais). O modelo 3 obteve uma RNA capaz de predizer satisfatoriamente a fraude avaliada a partir de análises consideradas de rotina em laticínios com uma RNA contendo 64 nodos na camada oculta, $R^{2}$ de 0,9935 e RMSE de 0,5779 para treinamento, $R^{2}$ de 0,9964 e RMSE de 0,4358 para validação.

Palavras-chave: análises de rotina, detecção de fraude, controle de qualidade.

\section{INTRODUCTION}

The identity and quality standards of powdered milk specified in Normative Instruction No. 53, dated 1 October 2018, of the Ministry of Agriculture, Livestock and Supply (MAPA) gives the following definition: The "product obtained by dehydrating whole cow's milk, skimmed or partially skimmed and suitable for human consumption, through technologically adequate processes". Accordingly, it stated that the sole and mandatory ingredient must be only cow milk (BRASIL, MINISTÉRIO DA AGRICULTURA, 2018).

In Brazil, the incorporation of powdered whey in powdered milk is one of the commonest fraudulent methods used. Powdered whey is an 
extensively available industrial co-product, $90 \%$ cheaper than milk because between 85 and $95 \%$ of the milk volume is converted into whey during the production process of cheese. While the fraud executed in powdered milk raises the manufacturer's profitability, it lowers the nutritional value of the food. This occurs due to the reduced protein and fat levels, apart from inducing changes in the product in terms of the technological properties (VINCIGUERRA et al., 2019).

Fraud done by the addition of whey to milk powder can be detected by establishing the presence and quantity of caseinomacropeptide (CMP). The official MAPA methodology to identify this type of fraud involves high performance ultraviolet liquid chromatography (BRASIL, MINISTÉRIO DA AGRICULTURA, 2006). However, as this necessitates complex and expensive equipment, which most food industries cannot afford, it can also at times give falsepositive results. This occurs because the enzymes of certain psychrotrophs, which are microorganisms that produce a "pseudo CMP", break down the casein molecule (MILANEZE et al., 2018).

In order to detect the adulteration of powdered milk with whey, a few alternative techniques are being tested, such as near infrared (NIR) spectroscopy (CATTANEO; HOLROYD, 2013; PASQUINI, 2018); mid-infrared (MID) spectroscopy (ROMERO GONZALEZ; COBUCCIO; DELATOUR, 2019)and Raman spectroscopy (KARUNATHILAKA et al., 2017). In fact, (CALLAO; RUISÁNCHEZ, 2018) stated that food fraud can be more accurately detected by combining the data drawn from both spectra and statistical outcomes. However, these methods fail to suitably facilitate quality control in food industries as they necessitate analysis over a long term, besides involving the use of expensive equipment and materials.

In light of the intensely complex technologies, high expenditure and financial constraints, great interest has been generated in detecting and quantifying this fraudulent practice by routine analyses of the dairy products. This search is justified and can be conducted in the quality control laboratories of most food industries, using simple and cost effective methods.

It must be acknowledged that the isolated outcomes of these analyses do not provide reliable proof of such fraudulent practice. Therefore, Artificial Neural Networks (ANNs) have proven to be useful tools to correlate all the results of the analyses with product fraud. The ANNs are computational models that identify variable input and output patterns, and are able to estimate solutions for the data, which until that point had been unrecognized by the network, regarding a principal problem (PAPPU; GUMMADI, 2017)

Recently, Artificial Neural Networks have been investigated as a tool that can be used in the food industry, besides many others, for the prediction of quality parameters (VIEIRA et al., 2019; ZHU et al., 2021) productivity parameters (SOARES et al., 2015) and food fraud (ALVES DA ROCHA et al., 2015; BEHKAMI et al., 2019; CONDÉ; VALENTE; MINIGHIN, 2020).

Research dealing with the application of Artificial Neural Networks for the detection of milk fraud through the addition of whey have been restricted to these liquid products alone, without exploring the malpractices being done in the powdered products. Hence, this research selected the best Artificial Neural Network (ANN) to detect and quantify fraudulent practices by contaminating powdered milk with whey powder, using physicochemical analysis, by creating an accessible ANN for the industries in which powdered milk is employed as a product as well as an ingredient.

\section{MATERIALS AND METHODS}

\section{Acquiring the raw material}

For this study, whole milk powder and partially demineralized whey powder $(40 \%)$ were purchased in August 2018, in the city of Florestal MG. In the analysis, two brands and two batches of whole milk powder produced in the United States, and two brands and two batches of partially demineralized whey powder manufactured in Argentina, were used.

\section{Experimental design}

The practice of fraud using whey in powdered milk was evaluated by applying a completely randomized design (DIC) with one factor (percentage of fraud in the sample) and 103 degrees of adulteration $(0-12 \%$ ranging from $0.2 \% ; 12-$ $20 \%$ varying in $0.25 \% ; 21-30 \%$ variations in $1 \%$ and $100 \% \mathrm{p} / \mathrm{p}$ ). Three replications was done in all, and 309 experimental units (UE) were conducted.

\section{Sample preparation}

The samples of powdered milk and whey were weighed randomly using an analytical balance (AUY 220 Shimadzu), and mixing was done based the percentages of fraud cited. Thereafter, the samples were diluted in the proportion of $0.1625 \mathrm{~g} /$ $\mathrm{mL}$ to acquire a consistency as close as possible to whole fluid milk. These were packed in sterile plastic bottles containing azidiol tablets, and refrigerated 
in Styrofoam boxes containing ice sheets, until they were analyzed.

\section{Physicochemical analysis}

The fat $(\mathrm{g} / 100 \mathrm{~g})$, cryoscopy $\left({ }^{\circ}\right.$ Hortvert), total solids $(\mathrm{g} / 100 \mathrm{~g})$, defatted dry extract $(\mathrm{g} / 100 \mathrm{~g})$, lactose $(\mathrm{g} / 100 \mathrm{~g})$, protein $(\mathrm{g} / 100 \mathrm{~g})$ and casein $(\mathrm{g}$ $/ 100 \mathrm{~g}$ ) were analyzed using the milk analyzer equipment (CombiScope FTIR A600, Delta) under Fourier Transform Infrared (FTIR) spectroscopy.

\section{Modeling by Artificial Neural Networks}

The multilayer perceptron with feedforward architecture network was used. To analyze the different ANN topologies, the neurons in the hidden layer were varied in number from two to ninety, at two by two intervals, to a sum of 45 topologies.

From among the three RNA models tested, the first one had the input layer made up using the results drawn from the fat, cryoscopy, total solids, defatted dry extract, lactose, protein and casein analyzed. The second model excluded the findings of the casein analysis from the input layer because of its high complexity and cost, from a laboratory perspective. In the third model, the input layer was made up precisely using only the results of analyses accepted as low in cost and of the standard routine in dairy products, namely fat, defatted dry extract, cryoscopy and total solids. However, for all the models, the output layer was composed by using the percentage of fraud present in the samples.

Supervision of the training was done employing the back propagation algorithm and the hyperbolic tangent activation function. For the training validation, two methods were tested: In the Holdback technique, $25 \%$ of the database was used validate the network. In the K-fold method, the database was categorized into five same-sized subsets, which alternated between four subsets for training and one for validation.

\section{Analysis of results}

The best ANN was selected depending upon the performance coefficient which best represented the association between the coefficient of determination $\left(\mathrm{R}^{2}\right)$ and Root Mean Square Error (RMSE) of the training and validation steps, calculated through equation 1 . The tests were done using the JMP 14 software.

$$
\text { coefficient }=\frac{R^{2} \text { training }+R^{2} \text { validation }}{\text { RMSEtraining }+ \text { RMSEvalidation }}
$$

\section{RESULTS AND DISCUSSION}

\section{Physicochemical analysis}

The degrees to which the levels of fraud simulated earlier, affected the physicochemical analyses are shown in figure 1. It is evident that as the degree of fraud escalated the percentage of fat reduced (Figure 1A). This was because of the lower fat percentage in whey than in milk. This difference in the fat concentration is observed when the dough is separated from the whey during the enzymatic coagulation process, at which time the milk fat retention by the protein matrix of the cheese mass is noted (MARQUES, 2019).

The quantity of defatted dry extract (ESD) in figure $1 \mathrm{~B}$ revealed a propensity to show a rise in its value corresponding to the increase in the degree of fraud, which concurs with the results in terms of the fat content (Figure 1A). Further, because the whey added is $40 \%$ demineralized, there is a proportional increase in the concentration of the other components. Thus, the proportion of the defatted solids rises in relation to the total solids. As the degree of fraud increased, the levels of the protein (Figure 1C) and casein (Figure 1D) content decreased. The enzyme chymosin acts on casein, the principal milk protein, causing it to coagulate thus enabling the formation of the cheese mass. Thus, in whey, the casein content is much lower than in milk (MARQUES, 2019). As casein forms part of the protein percentage, the lower casein concentration in whey significantly affects the decay in the percentage of the milk proteins.

Corresponding to the increased degree of fraud (Figure 1E) the percentage of lactose also increased, as expected, because whey contains a higher percentage of dry-based lactose than does milk (BONDAN et al., 2018; GANJU; GOGATE, 2017).

The freezing point (cryoscopy) of milk (Figure 1F) showed a drop in value corresponding to the increased degree of fraud. This response can be linked to the rise in the fractions of a few of the solids present in the samples due to the added whey, which contains a higher lactose concentration; according to the literature, this is related to $75 \%$ of the milk solids (ROCHA; GUERRA, 2020). A negative relationship was reported between lactose and milk cryoscopy by COSTA et al., 2019.

The increase in the degree of fraud induced hardly any change in the content of total solids, showing neither increasing nor decreasing trends. This was anticipated because powdered milk and whey powder possess similar concentrations of total solids; and in the sample preparation, when one 


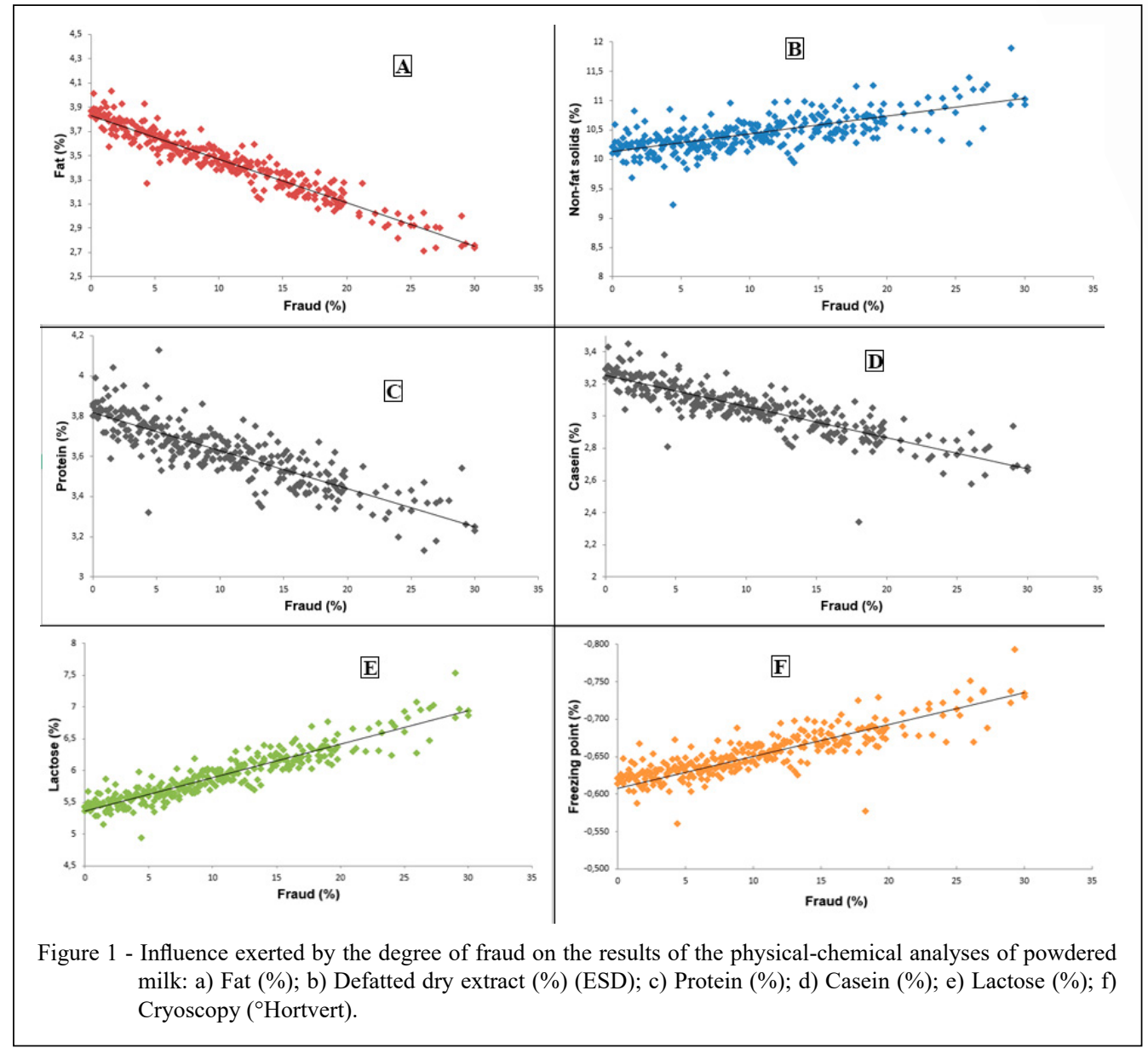

aliquot of powdered milk was removed it was replaced by the addition of the same aliquot of whey in dust.

\section{Performance of artificial neural networks}

In table 1, the list is presented of the outcomes of $\mathrm{R}^{2}$ and RMSE of the training and validation for the ten ANN topologies that revealed the best predicted performance for all the three models (1, 2 and 3 ). The ranking was done based on acquiring the highest coefficient of performance values (Equation 1).

Model 1 was shown to have the best ANN to predict fraud in powdered milk through the addition of demineralized whey powder, where the input variables were all the physicochemical analyses that had been done applying the K-fold method. Its topology showed the presence of 84 nodes in the hidden layer. As a statistical outcome, it revealed $\mathrm{R}^{2}$ as equal to 0.9971 and RMSE as equal to 0.3860 for training, and $\mathrm{R}^{2}$ as equal to 0.9973 and RMSE as equal to 0.3850 for validation. However, on analysis of the data given in table 1, it was evident that the ANN containing only two nodes in the hidden layer also gave good results and could enable the processing time and complexity to be minimized. Through Model 2, the best RNA that could predict fraud in powdered milk that had been adulterated with demineralized whey powder possessed the following input variables: fat, protein, lactose, total solids, defatted dry extract and cryoscopy, applying the K-fold technique. The topology included 72 nodes in the hidden layer, and its statistical findings showed that $\mathrm{R}^{2}$ was equal to 0.9937 and RMSE was equal to 0.5724 for training, and $\mathrm{R}^{2}$ was equal to 0.9953 and RMSE was equal to 0.4774 for validation. However, the ANN that contained only six nodes in the hidden layer also gave good results and could lower the processing time and complexity.

For Model 3 the best ANN that predicted fraud in powdered milk by the addition of demineralized whey powder possessed the following input variables: fat, defatted dry extract, cryoscopy and total solids, through the K-fold method. With 64 
Table 1 - Topology of the ten best ANNs to predict the degree of fraud in powdered milk for Models 1, 2 and 3.

\begin{tabular}{|c|c|c|c|c|c|c|c|}
\hline \multirow[b]{2}{*}{ Model } & \multirow[b]{2}{*}{ Method } & \multirow[b]{2}{*}{ Nodes } & \multicolumn{2}{|c|}{-------------'Training----------- } & \multicolumn{2}{|c|}{ 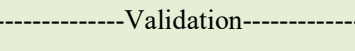 } & \multirow[b]{2}{*}{ Coefficient } \\
\hline & & & $\mathrm{R}^{2}$ & RMSE & $\mathrm{R}^{2}$ & RMSE & \\
\hline \multirow{10}{*}{1} & K-fold & 84 & 0.9971 & 0.3860 & 0.9973 & 0.3850 & 258.6745 \\
\hline & K-fold & 70 & 0.9936 & 0.5779 & 0.9980 & 0.3131 & 223.5326 \\
\hline & K-fold & 78 & 0.9939 & 0.5668 & 0.9973 & 0.3640 & 213.9264 \\
\hline & K-fold & 80 & 0.9926 & 0.6215 & 0.9969 & 0.3884 & 197.0148 \\
\hline & K-fold & 88 & 0.9962 & 0.4435 & 0.9931 & 0.5777 & 194.8077 \\
\hline & K-fold & 2 & 0.9941 & 0.5472 & 0.9953 & 0.5057 & 188.9366 \\
\hline & K-fold & 36 & 0.9937 & 0.5645 & 0.9953 & 0.5052 & 185.9392 \\
\hline & K-fold & 18 & 0.9953 & 0.4971 & 0.9929 & 0.5791 & 184.7275 \\
\hline & Holdback & 46 & 0.9947 & 0.5044 & 0.9942 & 0.5933 & 181.1836 \\
\hline & K-fold & 90 & 0.9971 & 0.3811 & 0.9900 & 0.7353 & 177.9958 \\
\hline \multirow{10}{*}{2} & K-fold & 72 & 0.9937 & 0.5724 & 0.9953 & 0.4774 & 189.4682 \\
\hline & K-fold & 88 & 0.9931 & 0.6005 & 0.9957 & 0.4579 & 187.9055 \\
\hline & K-fold & 68 & 0.9937 & 0.5730 & 0.9950 & 0.4921 & 186.7239 \\
\hline & K-fold & 80 & 0.9936 & 0.5777 & 0.9950 & 0.4909 & 186.1061 \\
\hline & K-fold & 50 & 0.9934 & 0.5891 & 0.9948 & 0.5001 & 182.5343 \\
\hline & K-fold & 6 & 0.9905 & 0.7068 & 0.9969 & 0.3831 & 182.3480 \\
\hline & Holdback & 72 & 0.9920 & 0.6205 & 0.9963 & 0.4730 & 181.8344 \\
\hline & Holdback & 74 & 0.9888 & 0.7359 & 0.9978 & 0.3685 & 179.8727 \\
\hline & K-fold & 26 & 0.9936 & 0.5700 & 0.9945 & 0.5404 & 179.0461 \\
\hline & K-fold & 58 & 0.9938 & 0.5712 & 0.9940 & 0.5394 & 178.9764 \\
\hline \multirow{10}{*}{3} & K-fold & 64 & 0.9935 & 0.5779 & 0.9964 & 0.4358 & 196.2858 \\
\hline & K-fold & 66 & 0.9935 & 0.5771 & 0.9963 & 0.4454 & 194.5956 \\
\hline & $\mathrm{K}$-fold & 72 & 0.9936 & 0.5732 & 0.9960 & 0.4611 & 192.3568 \\
\hline & K-fold & 74 & 0.9928 & 0.6068 & 0.9964 & 0.4367 & 190.6350 \\
\hline & K-fold & 56 & 0.9932 & 0.5899 & 0.9958 & 0.4723 & 187.2453 \\
\hline & K-fold & 60 & 0.9931 & 0.5945 & 0.9956 & 0.4832 & 184.5460 \\
\hline & K-fold & 22 & 0.9927 & 0.6094 & 0.9957 & 0.4775 & 182.9442 \\
\hline & $\mathrm{K}$-fold & 62 & 0.9925 & 0.6183 & 0.9958 & 0.4706 & 182.6038 \\
\hline & K-fold & 68 & 0.9926 & 0.6158 & 0.9957 & 0.4752 & 182.2566 \\
\hline & K-fold & 30 & 0.9929 & 0.6013 & 0.9953 & 0.4969 & 181.0522 \\
\hline
\end{tabular}

nodes in the hidden layer in its topology, the statistical results showed $\mathrm{R}^{2}$ equal to 0.9935 and RMSE equal to 0.5779 for training, and $\mathrm{R}^{2}$ equal to 0.9964 and RMSE equal to 0.4358 for validation.

In this instance, the network processing could not be simplified by employing a structure having only a few nodes in the hidden layer. This was because it was observed that such a decrease would be indicative of a significant rise in the RMSE. This took place because the lowered number of variables in the input layer required the presence of a more complex ANN to accomplish the data processing.
When the three models tested were compared, the K-fold method had the highestefficiency in all the cases because it obtained higher coefficients than when the Holdback technique was used. The best performance produced by using the K-fold method suggests that the database was inadequate in terms of size and randomness, necessitating its categorization into five groups, which alternated between training and validation (SILVA et al., 2010).

For all the three models, the values of the statistical parameters reveal good predictability by the ANNs, implying that the predicted data can 
very closely reflect the real facts. This observation was noted during the training and validation stages, thus indicating the capacity of the acquired ANNs to learn and generalize the behavior of the system under investigation.

Due to these findings and considering the simple physicochemical analyses used with reference to the input layer in Model 3, this could be accepted as the best technique to detect fraud determined by the food industry.

Thus, Artificial Neural Networks were employed in the prediction of fraud in fluid milk through the addition of liquid whey (MONTEIRO, 2015). The findings from the Fourier Transform Infrared (FTIR) spectroscopy were entered as the input data, while the CMP quantity acquired by high performance liquid chromatography was used as the output data. Results reported by the author concurred with those achieved in this research, showing a rise in the validation RMSE in relation to the training value, suggesting a reduction in the generalization capacity of the network when data not utilized in training are presented. However, the RNA acquired has lower applicability because the analyses that were used as the input and output data are both complex and expensive. Therefore this, restricts the use of the RNA attained to only the regulatory agencies via the caseinomacropeptide quantification method, and not as a quality control substitute in the dairy and food industry.

In another study, one author employed the data drawn from the analyses of the fat, defatted dry extract, density, protein, lactose, mineral salts and cryoscopy as the input layer variables of the Artificial Neural Network to detect the fraud in the liquid milk by adding fluid whey (CONDÉ; VALENTE; MINIGHIN, 2020). However, these results were lower than those reported in the study cited earlier and the current study. The most suitable ANN identified by the researcher employing the back propagation algorithm reported 15 nodes in the hidden layer and showed that fat and density were the most affected variables when fraud was practiced. Fraudulent practice to the tune of $0,5,10$ and $20 \%$ showed standard deviations of $2.17 ; 4.41 ; 4.06$ and 1.66 , respectively, values higher than the mean square errors obtained in the present study. The reduced predictive ability of this ANN can be warranted by the 164 assays used in the database, which were less than the ones used in the present study and the degrees of fraud $(1,5,10$ and $20 \%$ ) which showed much higher intervals than those in the study.

\section{CONCLUSION}

The Artificial Neural Network has thus been proven to be a viable and effective methodology to detect fraud in whole milk powder to which partially demineralized whey powder was added as a adulterating agent, using physicochemical analyses; this was possible because of the high predictive capacity for the best topologies in all three models tested $\left(\mathrm{R}^{2}>0.9935\right.$ and $\left.\mathrm{RMSE}<0.5779\right)$. Model 3, in which main routine analyses in dairy products is used (fat, defatted dry extract, cryoscopy and total solids), is superior because it necessitates analyses that exclude the use of expensive equipment and is less complex, without any compromise in the results given by RNA. Therefore, this method showed great potential for use in the food industry, for quality control of the powdered milk samples cited, where the possibility of fraud using powdered whey as the agent is present.

\section{ACKNOWLEDGEMENTS}

To the Milk Quality Analysis laboratory at the Federal University of Minas Gerais in Belo Horizonte for performing the physical-chemical analyses and to SAS for making available for 30 days the use of the statistical package SAS JMP, version 14. This study was financed in part by the Coordenação de Aperfeiçoamento de Pessoal de Nível Superior - Brasil (CAPES) - Finance Code 001.

\section{DECLARATION OF CONFLICT OF INTERESTS}

The authors declare no conflict of interest. The founding sponsors had no role in the design of the study; in the collection, analyses, or interpretation of data; in the writing of the manuscript, and in the decision to publish the results.

\section{AUTHORS' CONTRIBUTIONS}

All authors contributed equally for the conception and writing of the manuscript. All authors critically revised the manuscript and approved of the final version.

\section{REFERENCES}

ALVES DA ROCHA, R. et al. Quantification of whey in fluid milk using confocal Raman microscopy and artificial neural network. Journal of Dairy Science, 2015. v.98, n.6, p.3559-3567. Available from: < http://dx.doi.org/10.3168/jds.2014-8548>. Accessed: Oct. 18, 2018. doi: 10.3168/jds.2014-8548.

BEHKAMI, S. et al. Classification of cow milk using artificial neural network developed from the spectral data of single- and three-detector spectrophotometers. Food Chemistry, 2019. v.294, n. May, p. 309-315. Available from: <https://doi.org/10.1016/j. foodchem.2019.05.060>. Accessed: Mar. 03, 2021. doi: 10.1016/j. foodchem.2019.05.060. 
BONDAN, C. et al. Milk composition of holstein cows: A retrospective study. Ciencia Rural, 2018. v.48, n.12, p.1-8. Available from: <http://dx.doi.org/10.1590/01038478cr20180123>. Accessed: Mar. 03, 2021. doi: 10.1590/0103$8478 \mathrm{cr} 20180123$.

BRASIL, MINISTÉRIO DA AGRICULTURA, P. E A. Instrução Normativa n 69 , de 13 de dezembro de 2006. Critério de avaliação da qualidade do leite in natura, concentrado e em pó, reconstituídos com base no método analítico oficial físico-químico denominado "Índice CMP”. Diário Oficial da União, 2006. v.53, n.9, p.1689-1699.

BRASIL, MINISTÉRIO DA AGRICULTURA, P. E A. Instrução Normativa ${ }^{\circ} 53$ de 1 de outubro de 218. Regulamento Técnico Mercosul Para Fixação de Identidade e Qualidade de Leite em Pó Diário Oficial da União, 2018. p.11-12.

CALLAO, M. P.; RUISÁNCHEZ, I. An overview of multivariate qualitative methods for food fraud detection. Food Control, 2018. v.86, p.283-293. Available from: <https://doi.org/10.1016/j. foodcont.2017.11.034>. Accessed: Mar. 03, 2021. doi: 10.1016/j. foodcont.2017.11.034.

CATTANEO, T. M. P.; HOLROYD, S. E. The use of near infrared spectroscopy for determination of adulteration and contamination in milk and milk powder: Updating knowledge. Journal of Near Infrared Spectroscopy, 2013. v.21, n.5, p.341-349. Available from: <https://doi.org/10.1255/jnirs.1077>. Accessed: Oct. 18, 2018. doi: $10.1255 /$ jnirs. 1077.

CONDÉ, V. A.; VALENTE, G. De F. S.; MINIGHIN, E. C. Milk fraud by the addition of whey using an artificial neural network. Ciencia Rural, 2020. v.50, n.7, p.1-8. Available from: $<$ http://doi. org/10.1590/0103-8478cr20190312>. Accessed: Mar. 04, 2021. doi: 10.1590/0103-8478cr20190312.

COSTA, A. et al. Heritability and repeatability of milk lactose and its relationships with traditional milk traits, somatic cell score and freezing point in Holstein cows. Animal, 2019. v.13, n.5, p.909-916. Available from: <http://dx.doi.org/10.1017/ S1751731118002094>. Accessed: Mar. 04, 2021. doi: 10.1017/ S1751731118002094.

GANJU, S.; GOGATE, P. R. A review on approaches for efficient recovery of whey proteins from dairy industry effluents. Journal of Food Engineering, 2017. v.215, p.84-96. Available from: <http://doi.org/10.1016/j.jfoodeng.2017.07.021>. Accessed: Oct. 20, 2018. doi: 10.1016/j.jfoodeng.2017.07.021

MARQUES, C. Qualidade nutricional e sensorial do queijo colonial do sudoeste do Paraná. In: Cartilha de Segurança alimentar na produção de queijos. Queijo colonial artesanal. Cap. 03. 2019, p.37-60.

MILANEZE, H. S. et al. Microbiological, chemical, physical, and proteolytic activities of raw milk after thermal processing. Arquivo Brasileiro de Medicina Veterinaria e Zootecnia, 2018. v.70, n.5, p.1625-1632. Available from: <http://dx.doi. org/10.1590/1678-4162-9662>. Accessed: Mar. 03, 2021. doi: $10.1590 / 1678-4162-9662$
MONTEIRO, F. K. De C. Utilização da espectroscopia de infravermelho próximo para quantificação de adição de soro em leite. 2015. 86f. Dissertação (Mestrado em Ciência e Tecnologia do Leite e Derivados) - Curso de pós-graduação em Ciência e Tecnologia do Leite e Derivados, Universidade Federal de Juíz de Fora.

PAPPU, S. M. J.; GUMMADI, S. N. Artificial neural network and regression coupled genetic algorithm to optimize parameters for enhanced xylitol production by Debaryomyces nepalensis in bioreactor. Biochemical Engineering Journal, 2017. v.120, p.136-145. Available from: <http://dx.doi.org/10.1016/j. bej.2017.01.010>. Accessed: Mar. 04, 2021. doi: 10.1016/j. bej.2017.01.010.

PASQUINI, C. Near infrared spectroscopy: A mature analytical technique with new perspectives - A review. Analytica Chimica Acta, 2018. v.1026, p.8-36. Available from: < https://doi. org/10.1016/j.aca.2018.04.004>. Accessed: Mar. 07, 2021. doi: 10.1016/j.aca.2018.04.004.

ROCHA, J. M.; GUERRA, A. On the valorization of lactose and its derivatives from cheese whey as a dairy industry by-product: an overview. European Food Research and Technology, 2020. v.246, n.11, p.2161-2174. Available from: <https://doi. org/10.1007/s00217-020-03580-2>. Accessed: Mar. 07, 2021. doi: $10.1007 / \mathrm{s} 00217-020-03580-2$.

ROMERO GONZALEZ, R. R.; COBUCCIO, L.; DELATOUR, T. Reconstitution followed by non-targeted mid-infrared analysis as a workable and cost-effective solution to overcome the blending duality in milk powder adulteration detection. Food Chemistry, 2019. v.295, n. May, p.42-50. Available from: <https://doi. org/10.1016/j.foodchem.2019.05.100>. Accessed: Mar. 07, 2021. doi: 10.1016/j.foodchem.2019.05.100

SOARES, F. C. et al. Predição da produtividade da cultura do milho utilizando rede neural artificial. Ciencia Rural, 2015. v.45, n.11, p.1987-1993. Available from: <http://dx.doi.org/10.1590/01038478cr20141524>. Accessed: Nov. 01, 2018. doi: 10.1590/0103$8478 \mathrm{cr} 20141524$

VIEIRA, G. N. A. et al. Real-time monitoring of milk powder moisture content during drying in a spouted bed dryer using a hybrid neural soft sensor. Drying Technology, 2019. v.37, n.9, p.1184-1190. Available from: <https://doi.org/10.1080 /07373937.2018.1492614>. Accessed: Mar. 10, 2021. doi: $10.1080 / 07373937.2018 .1492614$

VINCIGUERRA, L. L. et al. Chemometric tools and FTIRATR spectroscopy applied in milk adulterated with cheese whey. Quimica Nova, 2019. v.42, n.3, p.249-254. 9. Available from: $<$ http://dx.doi.org/10.21577/0100-4042.20170337>. Accessed: Mar. 10, 2021. doi: 10.21577/0100-4042.20170337.

ZHU, N. et al. Application of artificial neural networks to predict multiple quality of dry-cured ham based on protein degradation. Food Chemistry, 2021. v.344, p.128586. Available from: <https:// doi.org/10.1016/j.foodchem.2020.128586>. Accessed: Mar. 10, 2021. doi: 10.1016/j.foodchem.2020.128586. 